\title{
通年性喉頭アレルギーの抗原および喉頭所見
}

$$
\text { 井 門 謙太郎 }{ }^{1)} \text {. 平 川 勝 洋 }{ }^{1)} \text {. 渡 部 浩 }{ }^{2)}
$$

\section{Causative Antigens and Laryngeal Findings of Perennial Laryngeal Allergy}

\author{
Kentaro Imon $^{1)}$, Katsuhiro Hirakawa ${ }^{1)}$ and Hiroshi Watanabe ${ }^{2)}$
}

The clinical symptoms of laryngeal allergy are persistent cough, itching and irritation of the throat. We endeavored to shed light on features of antigens and laryngeal findings of laryngeal allergy. A clinical study focusing on the diagnosis of laryngeal allergy was carried out on 32 patients exhibiting a persistent cough, itching and irritation of the throat. The diagnosis of laryngeal allergy was confirmed by the effectiveness on H1-blockers along with the presence of specific IgE antibodies by RAST testing. Laryngeal allergy was diagnosed according to the criteria proposed by the Society of Study for Laryngeal Allergy in Japan (2005).

Eighteen of the 32 patients were diagnosed as having laryngeal allergy. A major positive perennial antigen in laryngeal allergy is house dust mite. In comparison to nasal allergy, moth and cockroach antigens has a higher positive frequency with laryngeal allergy.

The sensitivity and specificity of nasopharyngeal smears for laryngeal allergy were $67 \%$ and $79 \%$, respectively. H1-blocker was significantly effective with positive nasopharyngeal smears.

There were no typical laryngeal features in laryngeal allergy cases but patients with a higher effect of antihistamines exhibited pale laryngeal mucosa.

Key words : laryngeal allergy, perennial antigens, laryngeal findings, Nasopharyngeal smear

\section{は じめ に}

喉頭アレルギーは，慢性的な咳嗽や咽喉頭異常感を呈す る疾患である。本邦では 1988 年に喉頭アレルギー研究会 が組織され，1995 年には喉頭アレルギー研究会から喉頭 アレルギーの診断基準が示された。その後も何度か見直さ れ，その都度，新しい診断基準が提唱されている。比較的 新しい疾患概念でもあり，まだ解明されていない点も多い.

今回, 我々は通年性喉頭アレルギーの抗原は何か, 特徵 的な喉頭所見が認められるかについて検討したので報告す る。また, 当科では以前より乾性咳嗽や咽喉頭異常感症に おける咽頭スメア好酸球検査の有用性について注目してお り，喉頭アレルギーと咽頭スメア好酸球検査の関連につい ても検討したので合わせて報告する.

\section{対 象と方 法}

対象は, 2009 年 12 月から 2012 年 3 月までの間に 3 週 間以上持続する乾性咳嗽, 咽喉頭異常感を訴えて広島大学 病院耳鼻咽喉科を受診した症例 32 例である。 スギ花粉症 などの季節性喉頭アレルギーが明らかに疑われる症例は除 外した。年歯令は $24 \sim 78$ 歳で平均 57.7 歳, 性別は男性 14 例 女性 18 例であった。罹病期間は 2 ケ月〜 2 年で平均
は 3.8 ケであった。症状は咳嗽 12 例，異常感 20 例で あった。すべての症例に鼻汁, 咽頭スメアの好酸球検査, RIST, RAST (ハウスダスト1 (以下HD), ヤケヒョウヒ ダニ，スギ，カモガヤ，ブタクサ，ヨモギ，ゴキブリ，ガ， アスペルギルス, カンジダ, ピティロスポリウム, 動物上 皮マルチをセットで)，末梢血好酸球数を調べ，喉頭の電 子スコープ画像を撮影した，喉頭所見については，喉頭ア レルギー研究会で行っている共同研究で観察するべき喉頭 所見の内容を参考に，簡素化して分類した（表 1)。電子ス コープに取り込まれた画像はランダム化し，5名の耳鼻咽 喉科専門医が別々に評価した。 5 名の評価が一致しない場

\section{表 1 喉頭所見}
a. 披裂部を中心とした粘膜の浮腫 中等度 軽度 なし
b. 披裂部を中心とした粘膜の色調 蒼白 赤 正常
c. 声帯の浮腫 ありなし
d. 喉頭蓋の浮腫 ありなし

1) 広島大学耳鼻咽喉科・頭頸部外科

2) わたなべ耳鼻咽喉科・アレルギー科

1) Department of Otolaryngology-Head and Neck Surgery, Hiroshima University School of Medicine

2) Watanabe ENT Clinic 
1. 喘鳴を伴わない 3 週間以上持続する乾性咳嗽

2. 3 週間以上持続する咽喉頭異常感 (掻痒感, イガイガ感，痰が絡んだような感じ，チクチク した感じの咽頭痛など)

3.アトピー素因を示唆する所見（注 1)の1つ以上認める

4. 急性感染性喉頭炎, 特異的喉頭感染症 (結核, 梅毒, ジフテリアなど), 喉頭真菌症, 異物, 腫瘍などその他の咳の原因となる局所所見がないこと（典型的所見としては披裂部蒼白浮腫 状腫脹をみとめる)

5. 症状がヒスタミン H1 拮抗薬で著明改善もしくは消失する

追加次項 : a . 上記のうち 1 . が久落してもよい

注 1.アトピー素因を示唆する所見

(1) 喘息以外のアレルギー疾患の既往あるいは合併

(2) 末梢血好酸球増加

(3) 血清総 $\operatorname{IgE}$ 值の上昇

(4) 特異的 IgE 陽性

（5）アレルゲン皮内テスト即時型反応陽性

合は多数意見を採用した。咽頭スメア検査は, 中咽頭後壁 の粘液を綿棒にて採取し, スライドグラスに塗布後, 同時 に採取した鼻汁とともに当院の検査部に判定を依頼した. 好酸球検査の結果は $(-)$ 全視野に好酸球を認めない, $( \pm)$ 全視野に好酸球が数個程度, (+) 1 視野に好酸球が点在, $(++) 1$ 視野に好酸球が群在の 4 段階に分類した。また, すべての症例に抗ヒスタミン薬（エピナスチンまたはオロ パタジン常用量) を 2 週間投与した。

喉頭アレルギーの診断は, 検査結果と抗ヒスタミン薬の 効果より, 喉頭アレルギー多施設共同研究班の通年性喉頭 アレルギーのあまい診断基準案（2005 年案）（表 2) に基 づいて怙こなった。抗ヒスタミン薬の治療効果について は, 患者自身に視覚的アナログスケール (VAS) にて評価 してもらい, 症状の改善度が 50 \%以上を有効, $75 \%$ 以上 を著効， $100 \%$ を消失，50\%未満を無効とした．今回の検 討では, 有効以上を効果ありとした，また，有意差検定は t検定を用いて行った.

結

果

喉頭アレルギーと診断したのは 18 例であった。年齢性 別, 主訴, 鼻汁好酸球, 咽頭スメア好酸球検查の結果, 陽 性を示したアレルゲン, 抗ヒスタミン薬の治療効果を表 3 に示した。また，非喉頭アレルギーと診断した 14 例を表 4 に示した. 非喉頭アレルギーうちの 4 例は抗ヒスタミン 薬の治療効果が有効以上であったが，アトピー素因を認め なかったため, 非喉頭アレルギーと診断した。喉頭アレル ギー症例 18 例で陽性を示した抗原は $\mathrm{HD}$, ダニが最も多 く，以下スギ，ガ，ゴキブリの順であった（図 1). 18 例 のうちで通年性抗原陽性を示したのは 14 例であった。 そ の 14 例の陽性抗原の比率を, 当院アレルギー外来を受診 した通年性鼻アレルギー患者 20 例と比較した（図2）。 $\mathrm{HD}$ ，ダニは両群とも高率で差がなかった、ゴキブリ，ガ

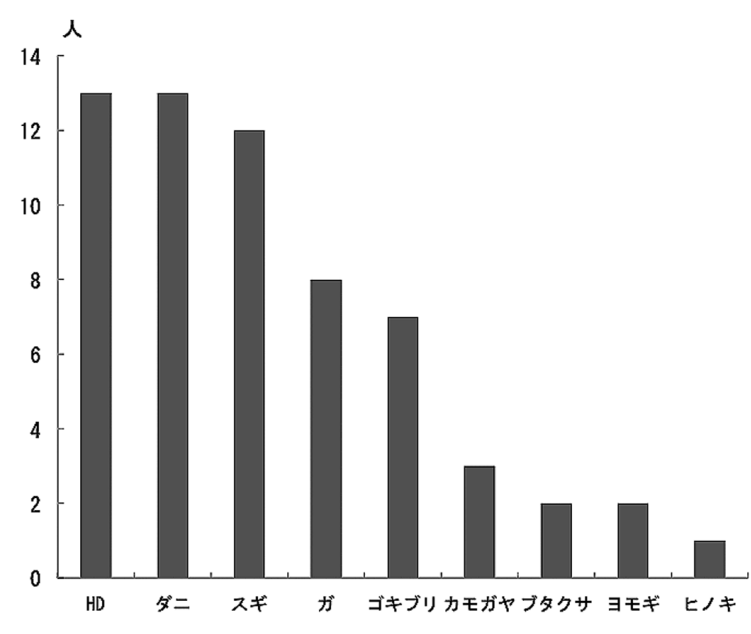

図 1 陽性抗原 (18 例)

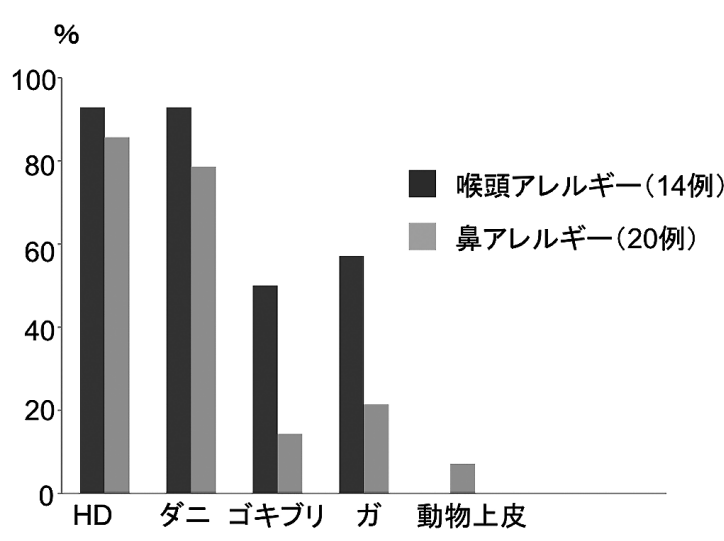

図 2 通年性陽性抗原 
表 3 喉頭アレルギー症例

\begin{tabular}{|c|c|c|c|c|c|}
\hline 症例 & 主訴 & 鼻汁好酸球 & 咽頭スメア & アレルゲン & 治療効果 \\
\hline $57 \mathrm{~F}$ & 咳 & $(++)$ & $(+)$ & $\mathrm{HD}$, ダニ, ゴキブリ, ガ & 著効 \\
\hline $36 \mathrm{M}$ & 異常感 & $(-)$ & $(+)$ & $\mathrm{HD}$ ，ヒノキ, カモガヤ, ヨモギ, ダニ, スギ, ブタクサ, ゴキブリ & 消失 \\
\hline $72 \mathrm{M}$ & 異常感 & $(-)$ & $( \pm)$ & スギ & 有効 \\
\hline $74 \mathrm{M}$ & 咳 & $(-)$ & $( \pm)$ & $\mathrm{HD}$, ダニ, スギ, ガ & 有効 \\
\hline $23 \mathrm{~F}$ & 咳 & $(-)$ & $(-)$ & $\mathrm{HD}$, ダニ, ガ, スギ, ヨモギ, ゴキブリ & 消失 \\
\hline $38 \mathrm{~F}$ & 異常感 & $(+)$ & $(+)$ & $\mathrm{HD}$, ダニ & 消失 \\
\hline $69 \mathrm{~F}$ & 異常感 & $( \pm)$ & $( \pm)$ & $\mathrm{HD}$, ダニ, ゴキブリ, ガ & 有効 \\
\hline $63 \mathrm{~F}$ & 異常感 & $(-)$ & $( \pm)$ & $\mathrm{HD}$, ダニ, カモガヤ, スギ, ガ & 有効 \\
\hline $59 \mathrm{~F}$ & 異常感 & $(-)$ & $( \pm)$ & スギ & 消失 \\
\hline $69 \mathrm{~F}$ & 異常感 & $( \pm)$ & $( \pm)$ & ゴキブリ，ガ & 有効 \\
\hline $65 \mathrm{M}$ & 咳 & $( \pm)$ & $(-)$ & $\mathrm{HD}$, ガ，ダニ，スギ，ブタクサ，ゴキブリ & 著効 \\
\hline $55 \mathrm{~F}$ & 異常感 & $(-)$ & $(-)$ & スギ & 著効 \\
\hline $27 \mathrm{~F}$ & 異常感 & $(-)$ & $(-)$ & $\mathrm{HD}$, ダニ, スギ & 消失 \\
\hline $56 \mathrm{~F}$ & 咳 & $(+)$ & $( \pm)$ & $\mathrm{HD}$, ダニ, スギ & 著効 \\
\hline $68 \mathrm{M}$ & 咳 & $(-)$ & $( \pm)$ & $\mathrm{HD}$ ，ダニ，ガ，スギ，カモガヤ，ゴキブリ & 著効 \\
\hline $38 \mathrm{M}$ & 異常感 & $( \pm)$ & $( \pm)$ & スギ & 有効 \\
\hline $33 \mathrm{M}$ & 異常感 & $(++)$ & $(-)$ & $\mathrm{HD}$, ダニ & 著効 \\
\hline $60 \mathrm{~F}$ & 異常感 & $(-)$ & $(-)$ & $\mathrm{HD}$, ダニ & 消失 \\
\hline
\end{tabular}

表 4 非喉頭アレルギー症例

\begin{tabular}{|c|c|c|c|c|c|}
\hline 症例 & 主訴 & 鼻汁好酸球 & 咽頭スメア & アレルゲン & 治療効果 \\
\hline $69 \mathrm{M}$ & 異常感 & $(-)$ & $(-)$ & $(-)$ & 無効 \\
\hline $65 \mathrm{~F}$ & 異常感 & $( \pm)$ & $(-)$ & スギ, カモガヤ & 無効 \\
\hline $78 \mathrm{M}$ & 咳 & $( \pm)$ & $(-)$ & $(-)$ & 無効 \\
\hline $70 \mathrm{M}$ & 異常感 & $( \pm)$ & $(-)$ & $(-)$ & 無効 \\
\hline $63 \mathrm{M}$ & 咳 & $(-)$ & $(-)$ & スギ & 無効 \\
\hline $65 \mathrm{~F}$ & 異常感 & $(-)$ & $( \pm)$ & $(-)$ & 有効 \\
\hline $63 \mathrm{M}$ & 異常感 & $(-)$ & $( \pm)$ & $(-)$ & 著効 \\
\hline $77 \mathrm{~F}$ & 異常感 & $(-)$ & $(-)$ & $(-)$ & 無効 \\
\hline $63 \mathrm{~F}$ & 異常感 & $(-)$ & $(-)$ & $(-)$ & 無効 \\
\hline $41 \mathrm{M}$ & 咳 & $(++)$ & $(-)$ & HD, ダニ, ガ & 無効 \\
\hline $49 \mathrm{~F}$ & 咳 & $(-)$ & $(-)$ & $(-)$ & 無効 \\
\hline $67 \mathrm{M}$ & 異常感 & $( \pm)$ & $(+)$ & $(-)$ & 著効 \\
\hline $58 \mathrm{~F}$ & 咳 & $(-)$ & $(-)$ & $(-)$ & 有効 \\
\hline $59 \mathrm{~F}$ & 咳 & $( \pm)$ & $(-)$ & $(-)$ & 無効 \\
\hline
\end{tabular}

は喉頭アレルギー患者の方が高率であった，また，喉頭 アレルギー患者ではカンジダ，アスペルギルス，ピティ ロスポリウム，動物上皮の陽性例はなかった。

全症例の喉頭所見の一覧を表 5 に示した。aに喉頭アレ ルギー症例， bに非喉頭アレルギー症例をまとめた。両群 間に特徵的な所見の差異は認めなかったが, 喉頭の色調 が蒼白であった症例は，喉頭アレルギー症例で 18 例中 9
例 $(50 \%)$ ，非喉頭アレルギーで 14 例中 5 例 $(35.7 \%)$ と 喉頭アレルギーに多かった。喉頭の色調別に抗ヒスタミ ン薬の治療効果を検討した。蒼白例と正常例の有効率は それぞれ $75 \%$ ，69\%と差は認められなかったが (図 3)， 症状消失例に関しては蒼白例が多く認められた（図 4). 浮腫については，16例で披裂に認めたが，喉頭蓋，声帯 に認めた症例はいなかった。浮腫の有無では治療効果の 
表 5 喉頭所見

\begin{tabular}{|c|c|c|c|c|c|}
\hline \multicolumn{2}{|c|}{ a 喉頭アレルギー } & \multicolumn{4}{|c|}{ b 非喉頭アレルギー } \\
\hline 症例 & 披裂部色調 & 披裂部浮腫 & 症例 & 披裂部色調 & 披裂部浮腫 \\
\hline $57 \mathrm{~F}$ & 正常 & 軽度 & $69 \mathrm{M}$ & 正常 & なし \\
\hline $36 \mathrm{M}$ & 蒼白 & なし & $65 \mathrm{~F}$ & 赤 & 軽度 \\
\hline $72 \mathrm{M}$ & 蒼白 & 軽度 & $65 \mathrm{~F}$ & 正常 & 軽度 \\
\hline $74 \mathrm{M}$ & 赤 & なし & $78 \mathrm{M}$ & 赤 & なし \\
\hline $23 \mathrm{~F}$ & 蒼白 & なし & $70 \mathrm{M}$ & 蒼白 & 軽度 \\
\hline $38 \mathrm{~F}$ & 蒼白 & なし & $63 \mathrm{M}$ & 正常 & なし \\
\hline $69 \mathrm{~F}$ & 蒼白 & なし & $65 \mathrm{~F}$ & 正常 & 軽度 \\
\hline $63 \mathrm{~F}$ & 正常 & 軽度 & $63 \mathrm{M}$ & 正常 & なし \\
\hline $59 \mathrm{~F}$ & 正常 & なし & $77 \mathrm{~F}$ & 蒼白 & 軽度 \\
\hline $69 \mathrm{~F}$ & 蒼白 & なし & $63 \mathrm{~F}$ & 正常 & なし \\
\hline $65 \mathrm{M}$ & 正常 & 軽度 & $41 \mathrm{M}$ & 蒼白 & 軽度 \\
\hline $55 \mathrm{~F}$ & 正常 & なし & $67 \mathrm{M}$ & 正常 & 中等度 \\
\hline $27 \mathrm{~F}$ & 蒼白 & なし & $58 \mathrm{~F}$ & 蒼白 & 軽度 \\
\hline $56 \mathrm{~F}$ & 蒼白 & 軽度 & $59 \mathrm{~F}$ & 蒼白 & 軽度 \\
\hline $68 \mathrm{M}$ & 正常 & なし & & & \\
\hline $38 \mathrm{M}$ & 赤 & なし & & & \\
\hline $33 \mathrm{M}$ & 正常 & 軽度 & & & \\
\hline $60 \mathrm{~F}$ & 蒼白 & 軽度 & & & \\
\hline
\end{tabular}

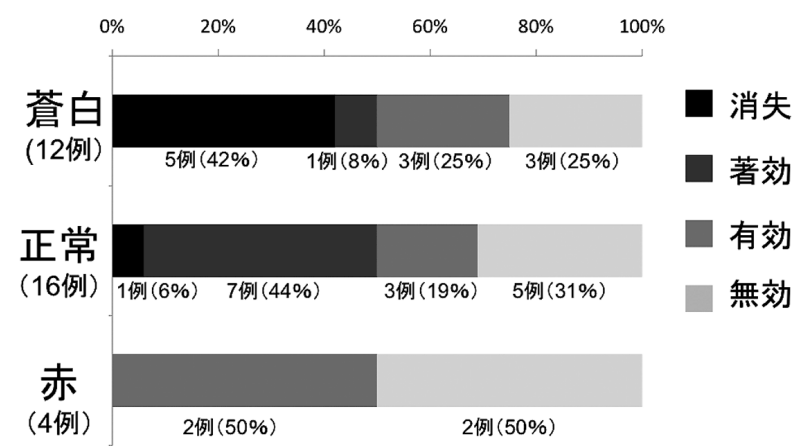

図 3 披裂部色調と抗ヒスタミン薬の治療効果

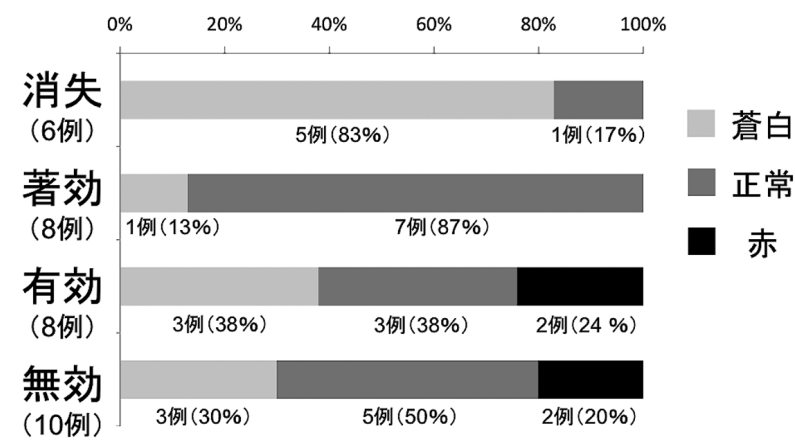

図 4 抗ヒスタミン薬の治療効果と披裂部色調
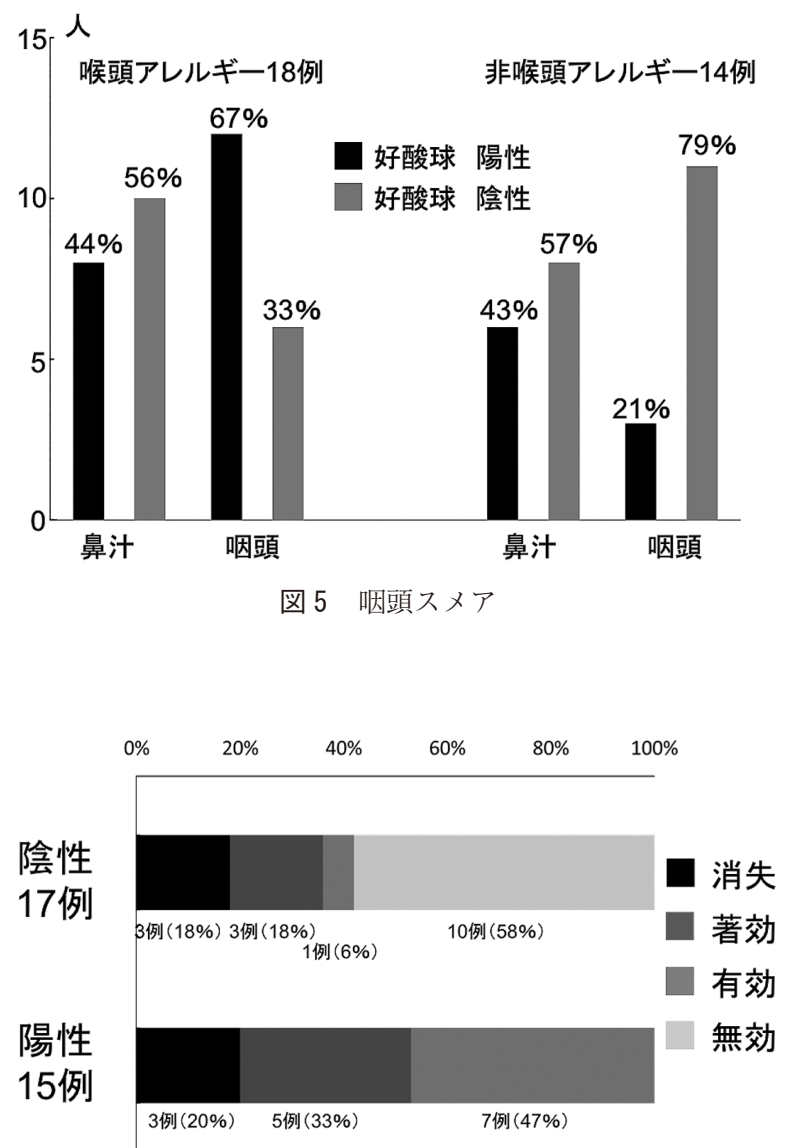

図 6 咽頭スメア中好酸球別の抗ヒスタミン薬の効果

明らかな差は認めなかった。

咽頭スメアは鼻汁に比べて, 好酸球が少量の例が多かっ たため，今回はどちらもェ以上を陽性として集計した。咽 頭スメア, 鼻汁とも非喉頭アレルギーに比較して喉頭アレ ルギー症例に好酸球陽性例が多く, その中でも鼻汁好酸球 よりも咽頭スメアの陽性例が多いという結果であった（図 5)。喉頭アレルギーの診断における咽頭スメア好酸球検査 の鋭敏度 (感度) は $67 \%$, 特異度は $79 \%$ であった。咽頭 スメア中好酸球の有無で, 抗ヒス夕ミン薬の効果を比較し た（図 6)。好酸球陽性例では，非喉頭アレルギー症例を含 めた全例で抗ヒスタミン薬治療による改善が認められ，好 酸球陰性例の有効以上 $42 \%$ に比べ有意に改善がみられた。

$$
\text { 考察 }
$$

喉頭アレルギーは, 1888 年にOsler ${ }^{1)} に よ り$ 初めて報告 され，その後も海外では幾つかの報告が続いた ${ }^{2)}$. その後, $\mathrm{Pang}^{3{ }^{3}}$ は喉頭アレルギーを，喉頭浮腫のため呼吸困難から 生命の危険に陥る可能性がある急性またはアナフィラキ シー型と, 鼻アレルギーや喘息症状に似てゆっくりした経 過を来す気道アレルギーの 1 亜型として慢性型に分類して いる。 しかし慢性型は診断が難しく, 多くは慢性喉頭炎と して診断されていた。しかし近年，咽喉頭症状を訴えるス 
ギ花粉症患者や，咽喉頭異常感症患者の中にアレルギーの 関与を疑わせる症例が存在することなどから, 慢性型の喉 頭アレルギーの存在が注目を集めるようになってきた.

本邦では, 1988 年に喉頭アレルギー研究会が組織され, 1995 年には喉頭アレルギーの診断基準が示された。その 後 2000 年と 2005 年に見直しが行われ，その度に新しい 診断基準が提唱されている. 2005 年案では花粉による季 節性のものと抗原のはっきりしない通年性に分類すること

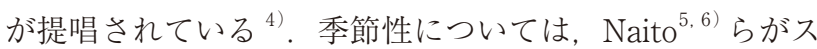
ギ花粉症患者を対象とした臨床的な研究を行い，又ギ花粉 症の咽喉頭症状の頻度は 38〜 70\%で, 抗ヒス夕ミン薬に よる初期治療が有効であったと報告している。さらに Sakurai $ら^{7)}$ は感作動物実験を行い，喉頭粘膜においてス ギ花粉抗原に対するI 型アレルギー反応が起きうることを 証明した，以上の結果から，スギ花粉症患者の咽㑨頭症状 は，喉頭アレルギーに由来するものであることが強く示唆 されている。

一方で，抗原を明確に特定することが難しい通年性の喉 頭アレルギーは，鑑別すべき類似疾患が数多くあること や，それらの疾患も解明されない点が多いことなどから， いまだに不明な点が多いのが現状である。喉頭アレルギー の 2 大症状は咽喉頭異常感と執拗な咳嗽である。咳嗽を主 症状とする疾患のうち，特に咳喘息，アトピー咳嗽，アレ ルギー性気管支炎，非喘息性好酸球性気管支炎の 4 疾患 は，いずれもアトピー素因の関与を疑わせ，鎮咳薬の無効 な乾性咳嗽を呈する。 その他にも胃食道逆流症, 後鼻漏症 候群，かぜ症候群後遷延性咳嗽，薬剂誘発性咳嗽，心因 性・習慣性咳嗽なども鑑別疾患に挙げられる。喉頭アレル ギーを独立疾患として診断するためには，これらの類似疾 患と的確に鑑別ができ，しかも一般臨床でも応用可能な診 断基準が必要である。2005 年に提唱された通年性喉頭ア レルギー診断基準では, 厳しい診断基準案 (以下厳しい基 準）とともにあまい診断基準案（以下あまい基準）も示さ れた，厳しい基準ではすべての鑑別すべき類似疾患が除外 され，純粋に喉頭アレルギーのみが選別されるが，あまい 基準では類似疾患が合併している可能性を否定できない． しかし，厳しい基準では喉頭アレルギーが存在していて も，類似疾患を合併していると除外される可能性がある.

今回我々は, 通年性喉頭アレルギー患者の抗原について 検討を行った。18例のうち通年性抗原が陽性を示したの は14例で，抗原の種類はHD，ヤケヒョウヒダニ，ゴキ ブリ，ガのみで，アスペルギルス，カンジダ，ピテイロス ポリウム等の真菌類はすべて院性であった，その抗原の陽 性率を, 当院アレルギー外来の鼻アレルギー患者と比較し た. HD，ダニは両群とも高率で差は無かったが，ゴキブリ， ガは喉頭アレルギー患者に高率に陽性であった，渡部ら ${ }^{8}$ は 1999 年に咽喉頭アレルギーにおける陽性アレルゲンの 検討を行い，同様に鼻アレルギー患者と比較している。そ れによると、コナヒョウヒダニが鼻アレルギーに比べ有意
に陽性率が低く、ゴキブリが有意に高いという結果を得て いる．また，ガも有意差はないが喉頭アレルギー患者に高 率であった，今回の検討では症例数が少なく，有意差は認 めなかったが，ゴキブリ，ガに関しては同様な結果であっ た。喉頭アレルギーに㧍いては，HD，ダニ抗原の関与が 最も重要であると考えられるが，一方でゴキブリ，ガ抗原 は喉頭アレルギーに特徵的な抗原である可能性が示唆され た。

喉頭アレルギー患者の喉頭所見は，非喉頭アレルギー症 例と比較して, 特徴的な所見は認めなかったが, 色調は蒼 白が多い傾向にあった，色調や浮腫の有無と治療効果を検 討したが，喉頭アレルギーの診断あるいは抗ヒスタミン薬 の治療効果を推測し得るような特徵的な喉頭所見は明らか ではなかった。

乾性咳嗽や咽喉頭異常感症に㧈ける咽頭スメア好酸球検 査の有用性についても検討した。咽頭スメア検査の利点 は，患者に負担を与えることなく簡便に行え，即座に結果 を得ることができることである，問題点としては，咽頭ス メアが咽頭局所のみの所見を反映しているのか，鼻咽腔や 下気道の病態を反映するのか明確ではないことである。渡 部らは ${ }^{9}$ 乾性咳嗽や咽喉頭異常感を主訴に受診した患者 64 例を咽頭スメア検査の結果で好酸球群，好中球群，非 炎症群に分類し，それぞれに塩酸アゼラスチンとトシル酸 スプラタスト, クラリスロマイシンとカルボシステイン, トフィソパムを投与し，その効果を検討している。全体の 有効率は $73.4 \%$ で, 好酸球群は $75 \%$ でやや有効以上で あったと報告しているが，好酸球群とそれ以外の群での， 抗ヒスタミン薬の効果の差が明らかではなかった。

今回我々は, 全ての症例に, 鼻汁拈よび咽頭スメアの好 酸球検査を施行し，抗ヒスタミン薬を投与した。咽頭スメ ア，鼻汁とも喉頭アレルギー群に好酸球陽性例が多く認め られた。しかし，鼻汁と咽頭スメア検査の結果には明確な 相関はなく，鼻汁よりも咽頭スメアの陽性例が多いという 結果であった。このことから咽頭スメア中好酸球の起源と して鼻汁が主要なものではないと思われた。 今回の検討で は喉頭アレルギー診断に扔ける咽頭スメア中好酸球検査の 鋭敏度 (感度) は $67 \%$, 特異度は $79 \%$ であり, 初期検査 として応用可能な展望が開けるのではないかと考える。 ま た咽頭スメア中の好酸球が陽性であった全例に抗ヒスタミ ン薬の投与で改善が認められ，陰性例に比べ有意に良い結 果であった。渡部らも有効率 $75 \%$ と報告しており，咽頭 スメア中の好酸球陽性例では抗ヒスタミン薬を第一選択に してもよいのではないかと思われた。

最後に，今回の検討は 32 例という少ない症例数ではあ るが，通年性喉頭アレルギー症例における，原因抗原およ び喉頭所見に関して，ある程度の傾向を明らかにできたと 考える. 今後も症例数を集め, 結果の精度を高めていくと ともに, 厳しい基準での喉頭アレルギー症例においても検 討していきたい. 


\section{ま と め}

1. 喉頭アレルギーの通年性抗原では $\mathrm{HD}$, ダニの陽性数 が多かった，鼻アレルギーと比較すると，ガ，ゴキブ リの陽性率が高い傾向にあった

2. 喉頭アレルギー症例において, 喉頭粘膜蒼白例が半数 に認められた。

3. 喉頭アレルギー診断における咽頭スメア好酸球検査の 鋭敏度 (感度) は $67 \%$, 特異度は $79 \%$ であった。

4. 咽頭スメア中好酸球陽性例は, 抗ヒスタミン薬が有意 に有効であった。

本論文の要旨は, 喉頭アレルギー研究会 2012 (名古屋) で発表した。

\section{参 考 文 献}

1) Osler Ww: Hereditary angio-neurotic aedema. Am J Med Sci 95 : 362-367, 1888.

2) Anderson $\mathrm{OE}$ : Laryngeal obstruction due to antibiotic therapy. Arch Otolarngol 54 : 34-37, 1952.

3) Pang LG : Allergy of the larynx, trachea and bronchial tree. Otolaryngol Clin North Am 7:719-734, 1974.

4）内藤健晴：喉頭アレルギー。慢性咳嗽の診断と治療に
関する治療指針（2005 年版），(藤村政樹）。16-21， 前田書店，金沢，2006.

5) Naito K, Iwata S, Yokoyama N : Laryngeal symptoms in patients exposed Japanese cedar pollen : allergic reactions and environmental pollution. Eur Arch Otorhinolaryngol 256 : 209-211, 1999.

6）伊藤周史, 内藤健晴, 斎藤正治ほか：塩酸フェキソフェ ナジンのスギ花粉症に対する野外比較試験による臨床 効果の検討。鼻アレルギーフロンティア $5: 80-85$, 2005.

7) Sakurai K, Naito K, Ishii G et al : Influence of local antigen exposure dose in the upper respiratory tract on sensitization with cedar pollen. Allergol Int 51 : 9-12, 2002.

8）渡部 浩, 長田理加, 竹野幸夫ほか：咽喉頭アレルギー に抢ける陽性アレルゲンの検討。喉頭 $11: 43-46$, 1999.

9）渡部 浩，井門謙太郎，石野岳志ほか：咳嗽，咽喉頭 異常感症例に打ける咽頭スメア検査．耳鼻臨床 補 102:50-53, 1999 .

別刷請求先 $\overline{7} 734-8551$ 広島市南区霞 1-2-3 広島大学病院耳鼻咽䚐科・頭頸部外科

井門謙太郎 